\title{
What Drives Bank Performance in Asean Countries? The Role of Bank-Specific, Macroeconomic and Regulations in Dual Banking System
}

Nurhafiza Abdul Kader Malim, Fatin Nur Hidayah Taib Khan, Tajol Ariffin Masron, Ema Izati Zull Kepili, Nik Hadiyan Nik Azman

To Link this Article: http://dx.doi.org/10.6007/IJARBSS/v11-i11/11190～DOI:10.6007/IJARBSS/v11-i11/11190

Received: 16 September 2021, Revised: 20 October 2021, Accepted: 30 October 2021

Published Online: 19 November 2021

In-Text Citation: (Malim et al., 2021)

To Cite this Article: Malim, N. A. K., Khan, F. N. H. T., Masron, T. A., Kepili, E. I. Z., \& Azman, N. H. N. (2021). What Drives Bank Performance in Asean Countries? The Role of Bank-Specific, Macroeconomic and Regulations in Dual Banking System. International Journal of Academic Research in Business and Social Sciences, 11(11), 2156-2167.

\section{Copyright: (c) 2021 The Author(s)}

Published by Human Resource Management Academic Research Society (www.hrmars.com) This article is published under the Creative Commons Attribution (CC BY 4.0) license. Anyone may reproduce, distribute, translate and create derivative works of this article (for both commercial and non0-commercial purposes), subject to full attribution to the original publication and authors. The full terms of this license may be seen at: http://creativecommons.org/licences/by/4.0/legalcode

Vol. 11, No. 11, 2021, Pg. $2156-2167$ 


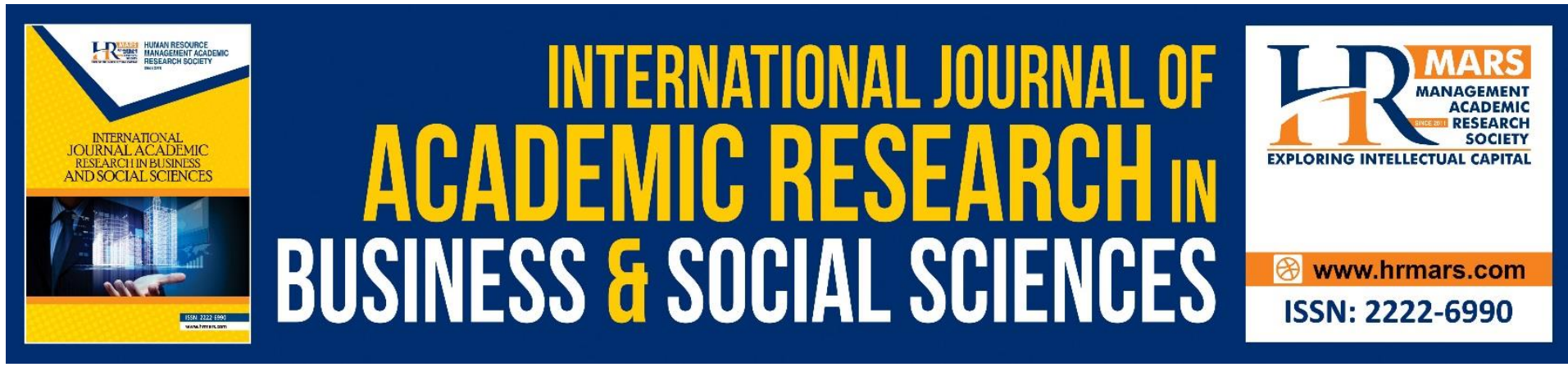

\title{
What Drives Bank Performance in Asean Countries? The Role of Bank-Specific, Macroeconomic and Regulations in Dual Banking System
}

\author{
Nurhafiza Abdul Kader Malim, Fatin Nur Hidayah Taib Khan, \\ Tajol Ariffin Masron, Ema Izati Zull Kepili, Nik Hadiyan Nik \\ Azman
}

School of Management, Universiti Sains Malaysia, Penang, Malaysia

\begin{abstract}
This paper examines the role of bank-specific, macroeconomic, and regulations on the performance of Islamic and conventional banks in ASEAN countries over the period 20092016 using a fixed-effects estimator. The results indicate that conventional and Islamic banks were significantly affected by the operating cost. We find the significant effects of bank concentration and credit risk on conventional banks' performance. For Islamic banks, we uncovered evidence suggesting that diversification and liquidity risk are important determinants of the performance of Islamic banks. Interestingly, the findings indicate that regulations are the key drivers of the performance of Islamic banks. Activity restrictions, supervisory power and Islamic regulation have a significant impact on the Islamic banks' performance. The findings highlight policy implications in improving bank performance, including reducing operating costs, less stringent supervisory power, robust Islamic regulation and effective risk management.
\end{abstract}

Keywords: Islamic Banks, Conventional Banks, Performance, ASEAN Countries, Regulations

\section{Introduction}

The banking sector plays a vital role in the financial system. A profitable banking sector is necessary for economic growth, better withstand financial shocks and contributes to financial stability (Athanasoglu, 2008). The impact of the global financial crisis has emphasized the need to further understand the determinants of bank performance. The analysis of the drivers that affect the performance is pertinent for the progress and resilience of the banking industry to external shocks. The findings of previous studies have remained inconclusive with various determinants in influencing the bank performance, including bank-specific, marketspecific, macroeconomic, institutions and regulations factors.

The Islamic banking sector continues to record rapid development over the years and is concentrated mainly in the Middle East and Asian countries. In terms of global Islamic banking assets share, Iran remains the largest market with $32.1 \%$. Malaysia and Indonesia are 
prominent in the ASEAN region, where the Islamic banking asset share accounts for $10.8 \%$ and $1.9 \%$ (IFSB, 2019). Given the remarkable development in Islamic banks, improvement in bank performance is vital for financial sustainability. The Islamic banking sector provides an interesting case for investigation due to its increasing role in the global financial system. This interesting analysis, particularly in the context of ASEAN countries, can help in better understanding the behavior of the dual banking system. This paper investigates the factors driving bank performance of Islamic and conventional banks in the ASEAN countries. The ASEAN region has not earned enough discussions in the banking literature. The study focuses on ASEAN banks due to the limited research for the region despite their increasingly important role in the global Islamic banking assets size. ASEAN countries also have a less sophisticated banking system compared to the United States and Europe.

This paper contributes to the literature in several ways. First, we compare the role of bank-specific, macroeconomic and regulations on the performance of Islamic and conventional banks in ASEAN countries. Second, we also examine the role of Islamic regulation on the performance of Islamic banks. Motivated by the ongoing debate on the determinants of bank performance, the analysis of the drivers that affect the performance is pertinent for the sustainability of the banking industry in the ASEAN countries. Furthermore, the effect of regulation on bank performance has been addressed in the literature for developed countries and emerging countries with mixed results. However, the impact is largely unexplored in the context dual banking system. This research provides insights on the determinant of the performance of Islamic and conventional banks, particularly in ASEAN countries.

The rest of this paper is organized as follows. The following section discusses the related literature on bank performance. Section 3 describes the methodology and Section 4 discusses the empirical results. Section 5 provides the conclusion and policy implications.

\section{Literature Review}

The literature on bank performance mainly follows the early work by Short (1979) and Bourke (1989). Previous studies have widely explored the factors that influence the banks' performance in various countries, samples and techniques. The empirical studies have focused on individual countries such as Athanasoglu (2008); Sufian and Habibullah (2010) and Tan (2017) and cross countries such as Molyneux and Thorton (1992); Dietrich and and Wanzeried (2014); Djalilov and Piesse (2017). The authors have incorporated the internal and external determinants in their analysis, such as bank-specific, market, macroeconomic factors. The existing literature suggests several factors that are likely to influence the bank performance, such as size, credit risk, market concentration, capital, GDP and inflation.

Dietrich and Wanzenried (2014) investigated the determinants of commercial banking profitability in low, middle and high-income countries from 1998-2012 with different profitability measures, namely, return on equity, return on assets and net interest margins. The authors demonstrated that the level of income has an important impact on the determinant of bank profitability. Furthermore, the findings show that the financial crisis negatively impacts high-income countries, resulting in lower profitability. Djalilov and Piesse (2017) analysed the determinants of bank profitability in transition countries of Central and Eastern Europe for the period 2000-2013 using GMM technique. The findings show that government spending and monetary freedom negatively impact the bank profitability and better capitalised banks are more profitable. Tan (2017) evaluated the impacts of competition and shadow banking on the profitability of the Chinese banking industry. To 
measure competition, the author used the Boon indicator. The results show that shadow banking that generally focuses on providing credits to micro, small and medium enterprises has a significant and positive impact on bank profitability in China. Focusing on the impact of efficiency on bank profitability with different levels of risk and degree of competition, Fang et al (2019) found that the impact is more substantial when banks undertake higher levels of risk and face higher degrees of competition.

The empirical literature on bank performance focused mainly on the developed countries and developing countries. However, research directed to ASEAN countries, particularly comparing countries operating in the dual banking system, is limited. Bashir (2003); Sufian and Zulkhibri (2015) focus their analysis on Islamic banking profitability in MENA banking sectors, Izhar and Asuthay (2007) in Indonesia and Wasiuzzaman and Tarmizi (2010) in Malaysia. Rashid and Jabeen (2016) examined the performance determinants between Islamic and conventional banks in Pakistan from 2000-2012. They constructed the financial profitability index based on CAMELS ratios. The findings show that operating efficiency, deposits and market concentration are important in explaining the performance of Islamic banks while reserves, operating efficiency and overheads are significant determinants of conventional banks' performance. Alam et al. (2018) examined the linkages between bank regulatory and supervisory structures associated with Basel III's pillars impact on Islamic banks' performance in Asia and Gulf Cooperation Council (GCC) using the two-step Generalized Methods of Moments (GMM) technique. They found that regulatory variables are positively significant with Islamic banks' performance in the Asian region but not in the GCC. In the MENA region, the findings by Mateev and Bachvarov (2021) suggest that regulation matters in determining the performance of Islamic banks.

\section{Methodology}

The empirical model is specified as follows:

$$
R O A_{i j t}=\alpha_{i}+\beta_{1} \text { Bank }_{i j t}+\beta_{2} \text { Market }+\beta_{3} \text { Macro }_{j t}+\beta_{4} \text { Regulation }_{j t}+\varepsilon_{i t}
$$

where $i, j$ and $t$ refer to bank, country and time, respectively. The dependent variable, $R O A$ represents the return on assets as the measure of bank performance. Bank vectors capture bank-specific variables, including size, operating cost, credit risk, liquidity risk, risk aversion and diversification. Market vectors capture bank concentration. Macro vectors include GDP growth and inflation. Regulation vectors consider activity restrictions, private monitoring, supervisory power and Islamic regulation. Table 1 provides descriptions of the variables and their sources. We employ the static panel data approach utilizing fixed effects estimator in our analysis. 
Table 1. Description of the variables

\begin{tabular}{|c|c|c|c|}
\hline Variable & Definition & Source & $\begin{array}{l}\text { Expected } \\
\text { sign }\end{array}$ \\
\hline \multicolumn{4}{|c|}{ Dependent Variables } \\
\hline ROA (\%) & $\begin{array}{l}\text { Ratio of net income to total } \\
\text { assets }\end{array}$ & FitchConnect & \\
\hline \multicolumn{4}{|c|}{ Independent Variables } \\
\hline I. Bank-spe & cific Variables & & \\
\hline Size & $\begin{array}{l}\text { Natural logarithm of total } \\
\text { assets (Petria et al., 2015). }\end{array}$ & FitchConnect & $+/-$ \\
\hline Operating cost & $\begin{array}{l}\text { Ratio of operating expenses to } \\
\text { total assets (Bougatef \& Korbi, } \\
\text { 2018). }\end{array}$ & FitchConnect & + \\
\hline Credit Risk & $\begin{array}{l}\text { Ratio of impaired loans to gross } \\
\text { loans (Fang et al., 2019). }\end{array}$ & FitchConnect & + \\
\hline Liquidity Risk & $\begin{array}{l}\text { Ratio of liquid assets to total } \\
\text { assets (Qi \& Yang, 2016) }\end{array}$ & \multicolumn{2}{|l|}{ FitchConnect } \\
\hline Risk Aversion & $\begin{array}{l}\text { Ratio of equity over total asset } \\
\text { (Bougatef \& Korbi, 2018). }\end{array}$ & FitchConnect & + \\
\hline Diversification & $\begin{array}{l}\text { Ratio of non-interest income to } \\
\text { gross revenue (Fang et al., } \\
\text { 2019). }\end{array}$ & FitchConnect & \\
\hline \multicolumn{4}{|c|}{ II. Macroeconomic Variables } \\
\hline GDP Growth & $\begin{array}{l}\text { Real GDP growth (Annual } \\
\text { percent change) (Tan, 2017). }\end{array}$ & WorldBank & $+/-$ \\
\hline Inflation & $\begin{array}{l}\text { Average consumer prices } \\
\text { (Annual percent change) (Tan, } \\
\text { 2017). }\end{array}$ & WorldBank & + \\
\hline
\end{tabular}

III. Market-specific Variable

$\begin{array}{lll}\text { Bank } & 3 \text { largest asset concentration } & \text { GlobalFinancial } \\ \text { concentration } & \text { (Naceur \& Omran, 2011). } & \text { Development Bank }\end{array}+$

IV. Regulation Variables

Activity The degree to which banks are

Restriction

Supervisory

Power

Private

Monitoring restricted or permitted to activities related to securities, insurance, and real estate markets and to ownership and control of non-financial firms (Poghosyan, 2013).

The degree to which the country's bank supervisory agency has the power to take specific actions (Lee \& Lu, 2015).

The degree of information that is released to officials and the public, auditing related
World Banking +

Regulation Data

World Banking Data +/Regulation

World Banking + 


$\begin{array}{ll} & \begin{array}{l}\text { requirements and whether } \\ \text { credit ratings are required } \\ \text { (Alam, 2014). }\end{array} \\ \text { Islamic } & \text { A dummy variable shows Dummy variable } \\ \text { Regulation } & \text { whether each country has a } \\ \text { separate regulatory framework } \\ \text { for Islamic banks (Alam et al. } \\ \text { 2018) }\end{array}$

\section{Data}

The sample consists of 22 Islamic banks and 129 conventional banks from five ASEAN countries, namely Indonesia, Thailand, Malaysia, Singapore and the Philippines. As shown in Table 2, there are 73 banks from Indonesia, 18 banks from Thailand, 38 banks from Malaysia, 7 banks from Singapore and 17 banks from the Philippines. The analysis covers the post-crisis period from 2009 to 2016 . We selected the sample based on data availability. The bank-level data are taken from FitchConnect Database. The data for bank concentration is from Global Financial Development Database. The macroeconomic data are obtained from World Bank Development Indicators. The regulation data are from Bank Regulation and Supervision Survey, World Bank.

Table 2. Banks in the sample by country

\begin{tabular}{llllll}
\hline & Indonesia & Thailand & Malaysia & Singapore & Philippines \\
\hline No. of Islamic banks & 5 & 1 & 14 & 1 & 1 \\
No. of conventional & 67 & 16 & 24 & 6 & 16 \\
Total no. of banks & 73 & 18 & 38 & 7 & 17 \\
\hline
\end{tabular}

\section{Results and Discussion}

Table 3 presents the summary statistics of the variables for full sample, Islamic and conventional banks in ASEAN countries. On average, the conventional banks have a substantially higher return on assets $(1.13 \%)$ than the Islamic banks $(0.26 \%)$ over the entire period. The operating cost of the Islamic banks (3.07\%), on average, is smaller than the conventional banks (3.52\%). Furthermore, Islamic banks exhibit higher credit risk $(5.81 \%)$ than conventional banks (3.96\%). 
Table 3. Summary statistics

\begin{tabular}{|c|c|c|c|c|c|c|c|c|c|}
\hline \multirow[t]{2}{*}{ Variable } & \multicolumn{3}{|c|}{ Full Sample } & \multicolumn{3}{|c|}{ Conventional Banks } & \multicolumn{3}{|c|}{ Islamic Banks } \\
\hline & $\begin{array}{l}\mathrm{Ob} \\
\mathrm{s}\end{array}$ & $\begin{array}{l}\text { Mea } \\
\mathrm{n}\end{array}$ & $\begin{array}{l}\text { Std. } \\
\text { Dev. }\end{array}$ & $\begin{array}{l}\mathrm{Ob} \\
\mathrm{s}\end{array}$ & $\begin{array}{l}\text { Mea } \\
\mathrm{n}\end{array}$ & $\begin{array}{l}\text { Std. } \\
\text { Dev. }\end{array}$ & $\begin{array}{l}\mathrm{Ob} \\
\mathrm{s}\end{array}$ & $\begin{array}{l}\text { Mea } \\
\mathrm{n}\end{array}$ & $\begin{array}{l}\text { Std. } \\
\text { Dev. }\end{array}$ \\
\hline ROA & $\begin{array}{l}84 \\
7\end{array}$ & 1.01 & 1.44 & $\begin{array}{l}73 \\
1\end{array}$ & 1.13 & 1.30 & $\begin{array}{l}11 \\
6\end{array}$ & 0.26 & 1.97 \\
\hline Size & $\begin{array}{l}84 \\
7\end{array}$ & 8.21 & 1.92 & $\begin{array}{l}73 \\
1\end{array}$ & 8.24 & 1.98 & $\begin{array}{l}11 \\
6\end{array}$ & 8.06 & 1.52 \\
\hline Operating Cost & $\begin{array}{l}84 \\
7\end{array}$ & 3.45 & 2.89 & $\begin{array}{l}73 \\
1\end{array}$ & 3.52 & 2.91 & $\begin{array}{l}11 \\
6\end{array}$ & 3.07 & 2.69 \\
\hline Credit Risk & $\begin{array}{l}84 \\
7\end{array}$ & 4.21 & 9.22 & $\begin{array}{l}73 \\
1\end{array}$ & 3.96 & 8.62 & $\begin{array}{l}11 \\
6\end{array}$ & 5.81 & 12.26 \\
\hline Liquidity Risk & $\begin{array}{l}84 \\
7\end{array}$ & $\begin{array}{l}19.4 \\
8\end{array}$ & 13.79 & $\begin{array}{l}73 \\
1\end{array}$ & $\begin{array}{l}19.9 \\
9\end{array}$ & 13.91 & $\begin{array}{l}11 \\
6\end{array}$ & $\begin{array}{l}16.2 \\
8\end{array}$ & 12.58 \\
\hline Diversification & $\begin{array}{l}84 \\
7\end{array}$ & $\begin{array}{l}24.3 \\
2\end{array}$ & 15.40 & $\begin{array}{l}73 \\
1\end{array}$ & $\begin{array}{l}25.3 \\
6\end{array}$ & 15.22 & $\begin{array}{l}11 \\
6\end{array}$ & $\begin{array}{l}17.7 \\
4\end{array}$ & 14.94 \\
\hline Risk Aversion & $\begin{array}{l}84 \\
7\end{array}$ & $\begin{array}{l}13.4 \\
7\end{array}$ & 10.57 & $\begin{array}{l}73 \\
1\end{array}$ & $\begin{array}{l}13.8 \\
8\end{array}$ & 9.38 & $\begin{array}{l}11 \\
6\end{array}$ & $\begin{array}{l}10.8 \\
9\end{array}$ & 15.97 \\
\hline $\begin{array}{l}\text { Bank } \\
\text { Concentration }\end{array}$ & $\begin{array}{l}84 \\
7\end{array}$ & $\begin{array}{l}46.3 \\
2\end{array}$ & 10.91 & $\begin{array}{l}73 \\
1\end{array}$ & $\begin{array}{l}45.5 \\
4\end{array}$ & 10.04 & $\begin{array}{l}11 \\
6\end{array}$ & $\begin{array}{l}51.2 \\
4\end{array}$ & 14.42 \\
\hline GDP & $\begin{array}{l}84 \\
7\end{array}$ & 4.93 & 1.65 & $\begin{array}{l}73 \\
1\end{array}$ & 4.94 & 1.67 & $\begin{array}{l}11 \\
6\end{array}$ & 4.90 & 1.56 \\
\hline Inflation & $\begin{array}{l}84 \\
7\end{array}$ & 3.62 & 2.04 & $\begin{array}{l}73 \\
1\end{array}$ & 3.75 & 2.06 & $\begin{array}{l}11 \\
6\end{array}$ & 2.84 & 1.69 \\
\hline $\begin{array}{l}\text { Activity } \\
\text { Restriction }\end{array}$ & $\begin{array}{l}84 \\
7\end{array}$ & 2.90 & 0.60 & $\begin{array}{l}73 \\
1\end{array}$ & 2.92 & 0.62 & $\begin{array}{l}11 \\
6\end{array}$ & 2.73 & 0.43 \\
\hline $\begin{array}{l}\text { Supervisory } \\
\text { Power }\end{array}$ & $\begin{array}{l}84 \\
7\end{array}$ & $\begin{array}{l}13.6 \\
5\end{array}$ & 0.48 & $\begin{array}{l}73 \\
1\end{array}$ & $\begin{array}{l}13.6 \\
5\end{array}$ & 0.42 & $\begin{array}{l}11 \\
6\end{array}$ & $\begin{array}{l}13.6 \\
8\end{array}$ & 0.79 \\
\hline $\begin{array}{l}\text { Private } \\
\text { Monitoring } \\
\text { Islamic Regulation }\end{array}$ & $\begin{array}{l}84 \\
7\end{array}$ & 6.15 & 0.46 & $\begin{array}{l}73 \\
1\end{array}$ & 6.15 & 0.45 & $\begin{array}{l}11 \\
6 \\
11 \\
6\end{array}$ & $\begin{array}{l}6.13 \\
0.99\end{array}$ & $\begin{array}{l}0.47 \\
0.09\end{array}$ \\
\hline
\end{tabular}

Tables 4 and 5 present the regression results of the determinants of performance of conventional and Islamic banks. The estimation results suggest some significant and interesting differences between conventional and Islamic banks. The results indicate that operating cost is significantly and negatively related to the performance of Islamic and conventional banks. The results suggest that the higher the operating costs, the lower the profitability of the banks. Weak bank management practices may increase operating costs and reduce their profits. The results also show that credit risk has a negative and significant impact on the performance of conventional banks. Conventional banks are exposed to more risky loans, which may lead to increased risk in default and lower performance.

Bank concentration has a negative and significant impact on the performance of conventional banks, suggesting that higher bank concentration tends to result in lower performance. The results suggest that greater concentration may increase the bank expansion with high expenses leading to lower revenue. The market-specific variable, such 
as bank concentration, has no significant impact on the performance of Islamic banks, and this reflects the inability of Islamic banks to exploit market concentration to increase their profits. The results also show that liquidity risk has a positive and significant impact on the Islamic banks' performance, indicating that Islamic banks with higher liquidity risk have high performance. Diversification has a positive and significant effect on the performance of Islamic banks. This result is in line with the finding of Tan (2017), suggesting that banks with more diversified businesses can generate higher income. This can be explained by profits stem from fees and commissions in the operations of Islamic banks. However, this is not the case for conventional banks as this variable is insignificant.

The analysis finds that the regulation variables have no significant impact on the conventional banks' performance. Interestingly, the regulation variables have a significant impact on the performance of Islamic banks. The findings show that activity restrictions positively affect the Islamic banks' performance, suggesting the higher degree of activity restrictions in banking may lower risk leading to higher performance. Supervisory power is negatively associated with the performance of Islamic banks, indicating that higher supervision by regulators leads to lower performance of Islamic banks. The results are consistent with Mateev and Bachvarov (2021), who find a negative and significant effect of supervisory power on bank performance in the MENA region. The results show that Islamic regulations play a positive role in increasing the performance of Islamic banks. Islamic banking is essentially guided by Shari'ah and entails regulations and supervision in their operations. The findings suggest that the effectiveness of Islamic regulations in improving the performance of Islamic banks. 
Table 4. Estimation results on the performance of conventional banks

\begin{tabular}{|c|c|c|c|c|c|c|}
\hline & (1) & (2) & (3) & (4) & (5) & (6) \\
\hline Size & $\begin{array}{l}-0.0184 \\
(0.951)\end{array}$ & $\begin{array}{l}-0.0598 \\
(0.838)\end{array}$ & $\begin{array}{l}-0.0638 \\
(0.845)\end{array}$ & $\begin{array}{l}-0.0342 \\
(0.915)\end{array}$ & $\begin{array}{l}-0.0575 \\
(0.864)\end{array}$ & $\begin{array}{l}0.0132 \\
(0.973)\end{array}$ \\
\hline Operating Cost & $\begin{array}{l}- \\
0.4015^{* * *} \\
(0.000)\end{array}$ & $\begin{array}{l}- \\
0.4032^{* * *} \\
(0.000)\end{array}$ & $\begin{array}{l}- \\
0.4009 * * * \\
(0.000)\end{array}$ & $\begin{array}{l}- \\
0.4027^{* * *} \\
(0.000)\end{array}$ & $\begin{array}{l}- \\
0.4007^{* * *} \\
(0.000)\end{array}$ & $\begin{array}{l}- \\
0.4012^{* * *} \\
(0.000)\end{array}$ \\
\hline Credit Risk & $\begin{array}{l}-0.0346 * \\
(0.067)\end{array}$ & $\begin{array}{l}-0.0344 * \\
(0.065)\end{array}$ & $\begin{array}{l}-0.0339 * \\
(0.072)\end{array}$ & $\begin{array}{l}-0.0344 * \\
(0.073)\end{array}$ & $\begin{array}{l}-0.0341^{*} \\
(0.070)\end{array}$ & $\begin{array}{l}-0.0354 * \\
(0.072)\end{array}$ \\
\hline Liquidity Risk & $\begin{array}{l}0.0024 \\
(0.663)\end{array}$ & $\begin{array}{l}0.0026 \\
(0.639)\end{array}$ & $\begin{array}{l}0.0022 \\
(0.702)\end{array}$ & $\begin{array}{l}0.0019 \\
(0.731)\end{array}$ & $\begin{array}{l}0.0022 \\
(0.697)\end{array}$ & $\begin{array}{l}0.0021 \\
(0.707)\end{array}$ \\
\hline Diversification & $\begin{array}{l}0.0116 \\
(0.130)\end{array}$ & $\begin{array}{l}0.0108 \\
(0.163)\end{array}$ & $\begin{array}{l}0.0106 \\
(0.177)\end{array}$ & $\begin{array}{l}0.0105 \\
(0.178)\end{array}$ & $\begin{array}{l}0.0107 \\
(0.174)\end{array}$ & $\begin{array}{l}0.0110 \\
(0.167)\end{array}$ \\
\hline Risk Aversion & $\begin{array}{l}0.0013 \\
(0.914)\end{array}$ & $\begin{array}{l}0.0011 \\
(0.927)\end{array}$ & $\begin{array}{l}0.0013 \\
(0.918)\end{array}$ & $\begin{array}{l}0.0016 \\
(0.902)\end{array}$ & $\begin{array}{l}0.0021 \\
(0.874)\end{array}$ & $\begin{array}{l}0.0039 \\
(0.790)\end{array}$ \\
\hline $\begin{array}{l}\text { Bank } \\
\text { concentration }\end{array}$ & & $\begin{array}{l}-0.0247^{*} \\
(0.099)\end{array}$ & $\begin{array}{l}-0.0253^{*} \\
(0.098)\end{array}$ & $\begin{array}{l}-0.0285^{* *} \\
(0.033)\end{array}$ & $\begin{array}{l}-0.0278 \\
(0.135)\end{array}$ & $\begin{array}{l}-0.0346^{*} \\
(0.069)\end{array}$ \\
\hline GDP & & & $\begin{array}{l}0.0157 \\
(0.179)\end{array}$ & $\begin{array}{l}0.0142 \\
(0.204)\end{array}$ & $\begin{array}{l}0.0178^{*} \\
(0.072)\end{array}$ & $\begin{array}{l}0.0169 \\
(0.134)\end{array}$ \\
\hline Inflation & & & $\begin{array}{l}0.0090 \\
(0.792)\end{array}$ & $\begin{array}{l}0.0117 \\
(0.723)\end{array}$ & $\begin{array}{l}0.0073 \\
(0.815)\end{array}$ & $\begin{array}{l}0.0105 \\
(0.763)\end{array}$ \\
\hline $\begin{array}{l}\text { Activity } \\
\text { restriction }\end{array}$ & & & & $\begin{array}{l}-0.1806 \\
(0.574)\end{array}$ & & \\
\hline $\begin{array}{l}\text { Supervisory } \\
\text { Power }\end{array}$ & & & & & $\begin{array}{l}-0.0635 \\
(0.723)\end{array}$ & \\
\hline $\begin{array}{l}\text { Private } \\
\text { Monitoring }\end{array}$ & & & & & & $\begin{array}{l}0.1115 \\
(0.389)\end{array}$ \\
\hline _cons & $\begin{array}{l}2.4679 \\
(0.345)\end{array}$ & $\begin{array}{l}3.9575 \\
(0.106)\end{array}$ & $\begin{array}{l}3.9068 \\
(0.163)\end{array}$ & $\begin{array}{l}4.3459 \\
(0.145)\end{array}$ & $\begin{array}{l}4.8181 \\
(0.103)\end{array}$ & $\begin{array}{l}2.9596 \\
(0.409)\end{array}$ \\
\hline Number of observations & 731 & 731 & 731 & 731 & 731 & 731 \\
\hline R-squared (within) & 0.3093 & 0.3125 & 0.3138 & 0.3147 & 0.3143 & 0.3162 \\
\hline R-squared (overall) & 0.0015 & 0.0018 & 0.0019 & 0.0031 & 0.0022 & 0.0038 \\
\hline R-squared (between) & 0.0004 & 0.0005 & 0.0006 & 0.0001 & 0.0004 & 0.0001 \\
\hline $\begin{array}{l}\text { Number of conventional } \\
\text { banks }\end{array}$ & 129 & 129 & 129 & 129 & 129 & 129 \\
\hline
\end{tabular}


Table 5. Estimation result on the performance of Islamic banks

\begin{tabular}{|c|c|c|c|c|c|c|c|}
\hline & (1) & (2) & (3) & (4) & (5) & (6) & (7) \\
\hline Size & $\begin{array}{l}0.4940 \\
(0.173)\end{array}$ & $\begin{array}{l}0.6226 \\
(0.104)\end{array}$ & $\begin{array}{l}0.1413 \\
(0.723)\end{array}$ & $\begin{array}{l}0.0545 \\
(0.891)\end{array}$ & $\begin{array}{l}0.1552 \\
(0.707)\end{array}$ & $\begin{array}{l}0.2741 \\
(0.409)\end{array}$ & $\begin{array}{l}0.1513 \\
(0.706)\end{array}$ \\
\hline Operating cost & $\begin{array}{l}- \\
0.9206^{* * *} \\
(0.000)\end{array}$ & $\begin{array}{l}- \\
0.9217^{* * *} \\
(0.000)\end{array}$ & $\begin{array}{l}- \\
0.9352^{* * *} \\
(0.000)\end{array}$ & $\begin{array}{l}- \\
0.9290^{* * *} \\
(0.000)\end{array}$ & $\begin{array}{l}- \\
0.9302^{* * *} \\
(0.000)\end{array}$ & $\begin{array}{l}- \\
0.9264^{* * *} \\
(0.000)\end{array}$ & $\begin{array}{l}- \\
0.9353^{* * *} \\
(0.000)\end{array}$ \\
\hline Credit Risk & $\begin{array}{l}-0.0251 \\
(0.252)\end{array}$ & $\begin{array}{l}-0.0238 \\
(0.279)\end{array}$ & $\begin{array}{l}-0.0217 \\
(0.244)\end{array}$ & $\begin{array}{l}-0.0179 \\
(0.347)\end{array}$ & $\begin{array}{l}-0.0221 \\
(0.241)\end{array}$ & $\begin{array}{l}-0.0191 \\
(0.315)\end{array}$ & $\begin{array}{l}-0.0217 \\
(0.246)\end{array}$ \\
\hline Liquidity Risk & $\begin{array}{l}0.0199^{* *} \\
(0.040)\end{array}$ & $\begin{array}{l}0.0182^{* *} \\
(0.038)\end{array}$ & $\begin{array}{l}0.0196^{* *} \\
(0.019)\end{array}$ & $\begin{array}{l}0.0189^{* *} \\
(0.023)\end{array}$ & $\begin{array}{l}0.0136 \\
(0.131)\end{array}$ & $\begin{array}{l}0.0181^{* *} \\
(0.035)\end{array}$ & $\begin{array}{l}0.0206^{* *} \\
(0.014)\end{array}$ \\
\hline Diversification & $\begin{array}{l}0.0243^{* *} \\
(0.030)\end{array}$ & $\begin{array}{l}0.0251^{* *} \\
(0.027)\end{array}$ & $\begin{array}{l}0.0210^{* *} \\
(0.035)\end{array}$ & $\begin{array}{l}0.0265^{* *} \\
(0.025)\end{array}$ & $\begin{array}{l}0.0249^{* *} \\
(0.018)\end{array}$ & $\begin{array}{l}0.0200^{*} \\
(0.051)\end{array}$ & $\begin{array}{l}0.0210^{* *} \\
(0.036)\end{array}$ \\
\hline Risk Aversion & $\begin{array}{l}0.0017 \\
(0.975)\end{array}$ & $\begin{array}{l}0.0028 \\
(0.960)\end{array}$ & $\begin{array}{l}-0.0101 \\
(0.824)\end{array}$ & $\begin{array}{l}-0.0018 \\
(0.970)\end{array}$ & $\begin{array}{l}-0.0106 \\
(0.824)\end{array}$ & $\begin{array}{l}-0.0164 \\
(0.724)\end{array}$ & $\begin{array}{l}-0.0100 \\
(0.827)\end{array}$ \\
\hline $\begin{array}{l}\text { Bank } \\
\text { concentration }\end{array}$ & & $\begin{array}{l}0.0052 \\
(0.312)\end{array}$ & $\begin{array}{l}0.0064 \\
(0.328)\end{array}$ & $\begin{array}{l}0.0061 \\
(0.341)\end{array}$ & $\begin{array}{l}-0.0524^{* *} \\
(0.014)\end{array}$ & $\begin{array}{l}-0.0103 \\
(0.596)\end{array}$ & $\begin{array}{l}0.0062 \\
(0.343)\end{array}$ \\
\hline GDP & & & $\begin{array}{l}0.0633 \\
(0.335)\end{array}$ & $\begin{array}{l}0.0658 \\
(0.314)\end{array}$ & $\begin{array}{l}0.0273 \\
(0.678)\end{array}$ & $\begin{array}{l}0.0466 \\
(0.516)\end{array}$ & $\begin{array}{l}0.0649 \\
(0.330)\end{array}$ \\
\hline Inflation & & & $\begin{array}{l}0.1692 \\
(0.170)\end{array}$ & $\begin{array}{l}0.1648 \\
(0.182)\end{array}$ & $\begin{array}{l}0.2022 \\
(0.123)\end{array}$ & $\begin{array}{l}0.1900 \\
(0.166)\end{array}$ & $\begin{array}{l}0.1661 \\
(0.183)\end{array}$ \\
\hline $\begin{array}{l}\text { Activity } \\
\text { restriction }\end{array}$ & & & & $\begin{array}{l}1.6167^{*} \\
(0.069)\end{array}$ & & & \\
\hline $\begin{array}{l}\text { Supervisory } \\
\text { Power }\end{array}$ & & & & & $\begin{array}{l}- \\
0.8569^{* * *} \\
(0.005)\end{array}$ & & \\
\hline $\begin{array}{l}\text { Private } \\
\text { Monitoring }\end{array}$ & & & & & & $\begin{array}{l}0.4541 \\
(0.299)\end{array}$ & \\
\hline $\begin{array}{l}\text { Islamic } \\
\text { Regulation }\end{array}$ & & & & & & & $\begin{array}{l}0.3076^{*} \\
(0.078)\end{array}$ \\
\hline _cons & $\begin{array}{l}-1.5294 \\
(0.503)\end{array}$ & $\begin{array}{l}-2.8353 \\
(0.285)\end{array}$ & $\begin{array}{l}0.4098 \\
(0.890)\end{array}$ & $\begin{array}{l}-3.4969 \\
(0.327)\end{array}$ & $\begin{array}{l}15.1436^{* *} \\
(0.021)\end{array}$ & $\begin{array}{l}-2.4940 \\
(0.329)\end{array}$ & $\begin{array}{l}0.0194 \\
(0.995)\end{array}$ \\
\hline
\end{tabular}


INTERNATIONAL JOURNAL OF ACADEMIC RESEARCH IN BUSINESS AND SOCIAL SCIENCES

Vol. 11, No. 11, 2021, E-ISSN: 2222-6990 ๑ 2021 HRMARS

\begin{tabular}{llllllll}
\hline $\begin{array}{l}\text { Number of } \\
\text { observations }\end{array}$ & 116 & 116 & 116 & 116 & 116 & 116 & 116 \\
$\begin{array}{l}\text { R-squared } \\
\text { (within) }\end{array}$ & 0.8464 & 0.8471 & 0.8626 & 0.8655 & 0.8688 & 0.8638 & 0.8629 \\
$\begin{array}{l}\text { R-squared } \\
\text { (overall) }\end{array}$ & 0.5665 & 0.5498 & 0.6462 & 0.7675 & 0.6971 & 0.6336 & 0.6450 \\
$\begin{array}{l}\text { R-squared } \\
\text { (between) }\end{array}$ & 0.6007 & 0.6016 & 0.6475 & 0.7892 & 0.7125 & 0.6703 & 0.6466 \\
$\begin{array}{l}\text { Number of } \\
\text { Islamic banks }\end{array}$ & 22 & 22 & 22 & 22 & 22 & 22 & 22 \\
\hline
\end{tabular}

$p$-values in parentheses

$* p<0.1, * * p<0.05, * * * p<0.01$

\section{Conclusion}

This paper examines the role of bank-specific, macroeconomic and regulatory factors on bank performance of Islamic and conventional banks using fixed effects panel regression. The sample consists of five ASEAN countries (Malaysia, Indonesia, Thailand, Singapore and Philippines) over the period of 2009 to 2016. The findings highlight the differential impact of the factors on the performance between conventional and Islamic banks. The findings show that the performance of conventional banks can be explained by operating cost, bank concentration and credit risk. We find evidence that bank-specific variables such as operating cost, diversification and liquidity risk are important determinants for Islamic banks. The results also suggest that conventional banks were not significantly affected by the regulation factors. However, regulation variables such as activity restrictions, supervisory power, and Islamic regulation have a significant impact on Islamic banks' performance.

The findings highlight several policy implications. We find that the operating cost has a negative influence on the performance of Islamic and conventional banks. Therefore, Islamic and conventional banks need to reduce the operating costs and strengthen their managerial efficiency in increasing the performance. The positive relation between diversification and bank performance of Islamic banks implies that the Islamic banks should diversify their bank financing portfolio and offer better quality financial services. The findings also show a negative link between credit risk and conventional banks' performance highlighting the importance of effective credit risk management in improving their performance. The impact of activity restrictions and Islamic regulations on the performance of Islamic banks are positive, suggesting that the regulators can strengthen the activity restrictions and Islamic regulations to improve the performance of Islamic banking. Furthermore, the results indicate that the supervisory power negatively influence Islamic banks' performance implying that less stringent supervision by the regulators may help Islamic banks in improving their performance.

This study has limitations in terms of the period of study as it focused on post-crisis analysis. Therefore, future research can shed light on comparing the performance of the dual banking system before and after the crisis period. 


\section{Acknowledgement}

The authors would like to express their gratitude to Universiti Sains Malaysia for providing the grant (304/PMGT/6316411) to fund this research.

\section{References}

Alam, N., Sara, Z., \& Rizvi, S. A. (2019). Ramifications of varying banking regulations on performance of Islamic banks. Borsa Istanbul Review, 19(1), 49-64.

Athanasoglou, P. P., Brissimis, S. N., Delis, M. D. (2008). Bank-specific, industry-specific and macroeconomic determinants of bank profitability. Journal of International Financial Markets, Institutions \& Money, 18, 121-136.

Bashir, A. H. (2003). Determinants of Profitability in Islamic Banks: Some Evidence from the Middle East. Islamic Economic Studies, 11(1), 31-57.

Bourke, P. (1989). Concentration and other determinants of bank profitability in Europe, North America and Australia. Journal of Banking and Finance, 13(1), 65-79.

Dietrich, A., Wanzenried, G. (2014). The determinants of commercial banking profitability in low-, middle-, and high-income countries. Quarterly Review of Economics and Finance, 54 (3), 337-354.

Djalilova, K., \& Piesse, J. (2016). Determinants of bank profitability in transition countries: What matters most? Research in International Business and Finance, 38, 69-82.

Fang, J., Lau, C. M., Lu, Z., Tan, Y., Zhang, H. (2019). Bank performance in China: A Perspective from Bank efficiency, risk-taking and market competition, Pacific-Basin Finance Journal, 56, 290-309.

Mateev, M., Bachvarov, P. (2021). Regulation, ownership and bank performance in the MENA region: Evidence for Islamic and conventional banks. Emerging Markets Review, 47, 100789.

Molyneux, P., Thorton, J. (1992). Determinants of European bank profitability: a note. Journal of Banking \& Finance, 16 (6), 1173-1178.

Rashid, A., \& Jabeen, S. (2016). Analyzing performance determinants: Conventional versus Islamic Banks in Pakistan, Borsa Istanbul Review, 16(2), 92-107.

Short, B. K. (1979). The relation between commercial bank profit rates and banking concentration in Canada, Western Europe and Japan. Journal of Banking and Finance, 3(4), 209-219.

Sufian, F., \& Zulkhibri, M. (2015). The Nexus between Economic Freedom and Islamic Bank Profitability in the MENA Banking Sectors, Global Business Review, 16(5S) 58S-81S.

Tan, Y. (2017). The impacts of competition and shadow banking on profitability: Evidence from the Chinese banking industry. North American Journal of Economics and Finance, 42, 89-106. 